\title{
COVID-19 Pandemi Sürecinin Yönetilmesinde Sosyal Pazarlama Aracı Olarak Kamu Spotların İncelenmesi: İçerik Analizi
}

\author{
DOI: 10.26466/opus.855071
}

$*$

\author{
Özgür Yeșilyurt * \\ * Dr. Öğretim Üyesi, Muş Alparslan Üniversitesi, Sağlık Bilimleri Fakültesi, Muş \Merkez \\ E-Posta: o.yesilyurt@alparslan.edu.tr \\ ORCID: $\quad$ 0000-0001-9252-3375
}

\section{Öz}

Sosyal pazarlama, günümüzde toplumsal faydanın ön plana çıkarılması ve farkındalık oluşturulması konularında bireylerde tutum ve davranış değişikliğine sebep olarak daha yaşanılabilir bir dünyayı mümkün kılmaya çalışan bir kavramdır. Kurum ve kuruluşlar toplum faydasını ön plana çıkarmak için sosyal sorumluluk projeleri kapsamında sosyal pazarlamaya önem vermekte özellikle çevre ve sağllk konularında kamu spotların kullanarak insanların bilinçlendirilmesini sağlamaktadır. Sosyal fayda için tutum ve davranış değişimi, genel olarak kamu sektörünün öncü olduğu sosyal pazarlama faaliyetlerinin temelini oluşturmaktadır. Kaтu spotlar, günümüzde sosyal pazarlama faaliyetlerinde bir araç olarak yoğun bir şekilde kullanılmaktadır. Bunun sebebi kamu spotlarının dijital çağda insanlara kolay ulaşmayı ve etkilemeyi mümkün kılacak yayın mecralarına sahip olmasıdır. Sosyal pazarlama aracı olarak kamu spotları, insanlara bilgi vermek, farkındalık oluşturmak, davranış değişikliği için ikna etmek, toplumsal sorunlara dikkat çekmek ve bu sorunlara çz̈̈üm önerileri sunmak amactyla kullanılmaktadır. Çalışmanın amacl; sosyal pazarlama bağlamında kamu spotlarının temalaştırılmasını sağlamaktır. Çalışmanin yöntemi; sosyal pazarlama bağlamında COVID-19 pandemi sürecinde Sağlık Bakanlığı tarafindan yayınlanmış olan 34 kamu spotunun içerik analizi kullanılarak temalaştırılmasıdır. Kamu spotlarn ile ilgili videolar nitel veri analizlerde kullanılan program yardımıyla kodlamalar yapılmış ve temalar oluşturulmuştur. Çalışmanın sonucunda ortaya çıkan temalar davranış kazandırma, farkındalık ve ikna etme'dir. Sosyal pazarlamanın kullanım amaçlarına uygun temalar ortaya çıkmışıır.

Anahtar Kelimeler: Sosyal Pazarlama, Kamu Spotları, Pandemi, COVID-19, İçerik Analizi. 


\title{
Use of Public Service Announcements as A Social Marketing Tool in Managing the COVID-19 Pandemia Process: A Content Analysis
}

\begin{abstract}
Social marketing is a concept that attempts to make the world more liveable by causing attitude and behavioural changes in individuals in bringing social benefit to the forefront and creating awareness. Institutions and organizations place importance to social marketing within the scope of social responsibility projects in order to bring the social benefit to the forefront, and provide awareness of people by using public service announcements, especially on environmental and health issues. Attitude and behavioural changes for social benefit generally form the basis of social marketing activities pioneered by the public sector. Today, public service announcements are used intensely as a tool in social marketing activities. This is because public service announcements have broadcast areas that will make it possible to reach and influence people easily in the digital era. As a social marketing tool, public service announcements are used to keep people informed, to create awareness, to persuade them to change behaviour, to attract attention to social problems and to propose solutions to these problems. The aim of the study is to provide public service announcement theming within the context of social marketing. The method of the study is to theme 34 public service announcements published by the Ministry of Health during the COVID-19 pandemic process in the context of social marketing by using a content analysis. Videos concerning public service announcements were coded and themes created with the help of the program used in qualitative data analysis. In conclusion, the emerging themes are behaviour acquisition, awareness and persuasion. Themes which are suitable for the intended use of social marketing have emerged.
\end{abstract}

Keywords: Social Marketing, Public Service Announcements, Pandemic, COVID-19, Content Analysis. 


\section{Giriş}

Sosyal pazarlama, geleneksel pazarlamaya farklı bir bakış açısı getirmiştir. Sosyal problemler ve davranış değişimleri sosyal pazarlamanın konuları arasında yer almaktadır. Bu konular pazarlama ile ilgili düşüncelerin ve pazarlama faaliyetlerinde kullanılan araçların tekrar yorumlanmasına imkan tanımıştır (Marangoz ve Aydın, 2019, s.11). Sosyal pazarlama, toplumsal sorunların çözülmesi konusunda farkındalık oluşturan, sosyal faydayı ön plana ç1karan, toplumsal sorunlarla ilgili tutum ve davranış değişikliğini hedefleyen bir pazarlama faaliyeti olarak kullanılmaktadır.

Uzun bir süredir çeşitli teknolojiler kullanılarak insanların davranışları değiştirilmeye çalışılmaktadır. Bu teknolojilerin birçoğu sosyal pazarlamanın özelliklerini taşıyor olsalar da hiçbiri sosyal pazarlama kadar davranış değişikliği konusunda etkili olmamış ve açık bir şekilde davranış değişikliğine odaklanmamıştır. Bunların kullanıldığı alanlar sağlık eğitimi, kitle iletişim, sosyal mobilizasyon, sosyal reklamcılık, toplumsal pazarlama, sosyal iletişim ve kamusal reklamcılıktır. Bu yaklaşımlar aşağıda ifade edilmiş olan düşünce ve eylem paradigmalarına uygun olacak şekilde karakterize edilmiştir (Andreasen, 1995'ten Aktaran: Dinan ve Sargent, 2000, s.4-5):

- Eğitim: Kampanyaların temel amacının eğitim olduğu bu yaklaşım, bireyi eğitmek ile bireyin tutum ve davranışlarını değiştirmek arasında doğrudan bir ilişki olduğunu varsaymaktadır.

- İkna Etme: Birey ya da grup üyeleri arasında arzu edilen ve hissedilen sosyal bir fikrin satılmasıdır. Gençleri uyuşturucuya hayır demeye ikna etmek için tasarlanmış bir dizi kampanya bu yaklaşıma dayanmaktadır.

- Davranış Değişikliği: Davranışçı bir bakış açısına göre insanlara davranış değişikliği için gerekli teknikleri öğrenme ve sonuçların ödüllendirici olacağını keşfetmeleri için fırsat verilmesidir.

- Sosyal Etki: Kültür ve sosyal yapı içerisinde bireysel davranışları etkilemenin zorluğunu tanımlayan bu yaklaşım, hali hazırda kurulmuş davranış kalıplarını güçlendirilmesi gerektiğini savunmaktadır.

Sosyal pazarlama faaliyetlerinde kullanılan konuları yönlendiren ve bu konularla ilgili çaba sarf eden kurumlar genelde kamu kurum ve kuruluşlaridır. Bunlar (Lee, ve Kotler, 2020, s.12):

- Hastalık Kontrol Önleme Merkezleri,

- Sağlık Bakanlığı, 
- Çevre koruma ajansi ve

- $\quad$ Ulusal Trafik Güvenliği İdaresi gibi ulusal kurum ve kuruluşlardır.

Ülkemizde ise kamu spotlarını yapan kurum ve kuruluşlar, Bakanlıklar (Sağlık Bakanlığı, Çevre ve Şehircilik Bakanlığı, İç İşleri bakanlığı gibi), sivil toplum kuruluşları genelde kamu spotlarını sosyal pazarlama aracı olarak kullanmaktadırlar.

İşletmenin önemli departmanları arasında yer alan pazarlama faaliyetleri temel işletme fonksiyonları içerisinde yer alsa da sağlık alanında kullanılması bazı eleştiriler yönelitilmektedir. Bu eleştiriler pazarlamanın sadece satış, reklam ve promosyona ilişkin faaliyetler olarak algılanmasından kaynaklanmaktadır. Sağlık hizmetlerinde pazarlamanın kullanılmasını zorunlu kılan nedenler; sağlık hizmeti alan bireylerin beklentilerinin artması, artan maliyetler, bilinçli tüketici sayılarındaki artıs ve sağlık hizmeti sunumunda kullanılan kaynakların etkili ve verimli kullanılmamasıdır. Ayrıca koruyucu sağlık hizmetlerine verilen önemin artması özellikle sosyal pazarlama faaliyetlerinin sağlık alanında yaygınlaşmasını sağlamıştır. Sağlık sektöründe sosyal pazarlama kullanımının yaygınlaşması insanların hayat standartlarının artmasinı sağlamaktadır (Bayın ve Akbulut, 2012, s.68).

Sosyal pazarlama genel olarak sağlıkla ilgili alanlarda kullanılmaktadır. Sigara bırakılması için sigaranın zararlarını anlatan, organ bağışı yapmaları için halkı bilinçlendiren ve bazı kanser türleri hakkında insanların bilinçlendirilmesi için sosyal pazarlama faaliyetleri yoğun olarak kullanılmaktadır. Korona virüsle mücadele edilen günümüzde salgının yayılımını azaltarak durdurmak için halkın bilinçlendirilmesi amacıyla sosyal pazarlama faaliyetleri kullanılmaktadır. Halkın bilinçlendirilmesi için kamu spotları çekilerek insanların virüse karşı almaları gereken önlemler anlatılarak dikkat etmeleri gereken konular gündeme getirilmeye çalışılmaktadır.

Koruyucu sağlık hizmetlerinde insanların bilinçlendirilmesi için sağlık alanında toplumsal sorunlara sebep olabilecek durumların ortadan kaldırılmasinda tanıtım kampanyaları ve kamu spotları yoğun olarak kullanılmaktadır. Sağlık Bakanlığı' nın desteği ile hazırlanmış kamu spotlarının pandemi sürecinin yönetilmesinde insanları bilinçlendirmek, salgının yayılımını azaltarak durdurmak için çeşitli mecralarda yayınlanan kamu spotlarının sosyal pazarlama bağlamında temalaştırılmasını sağlamak amacıyla bu çalışma ya- 
pılmıştır. Bu çalışmanın, kamu spotlarında verilmek istenen mesajları insanların doğru algılayıp algılamadıklarını ve toplumsal etki düzeyini görmek adına yapılacak yeni çalışmalara zemin hazırlayacağı düşünülmektedir.

Sosyal pazarlama ve kamu spotları ile ilgili literatürde özellikle içerik analizi kullanılarak yapılmış olan çalışma sayısı çok azdır. Genel olarak nicel çalı̧̧malara yer verilmiştir. Bu durum sonra ki çalışmaların temelini oluşturması açısından bu çalışmanın önemini artırmaktadır.

Yıldırım Becerikli'nin (2012) yapmış olduğu çalışmada; Sağlık Bakanlığının "Sigara pişmanlıktır." temalı kamu spotu ve AVEA'nın sigarayı bir metafor olarak kullandırdığı "Siz de bırakabilirsiniz." reklam filmi çözümlenmiştir. Odak grup çalışmalarıyla bulgular elde edilmiştir. Katılımcılar Sağlık Bakanlığı'nın kamu spotunda sigara bağımlılı̆̆ı olan yaşlı kişilerin karakterleri canlandırmasından kaynaklı olarak gençlerin özdeşlik duygusunu yaşayamadığını ve kamu spotunun içeriğinde yer alan fon müziği ile ölüm temasının korku yaratması sebebiyle kamu spotunu izlemediklerini ifade etmişlerdir. Bu kamu spotlarının sigara içenleri sigarayı bırakmaya ikna etme konusunda yetersiz olduğunu; sigara içmeyenlerin ise sigara içmeme tutumlarını sürdürmelerinde etkili olmadığını ifade etmişlerdir (Yıldırım Becerikli, 2012). Kurt ve Yılmaz Alarçi'nin (2019) üniversite öğrencilerinin kamu spotlarına ilişkin tutum ve beklentilerini ölçmek için yapmış oldukları çalışmada, üniversite öğrencilerinin tutumlarının demografik özelliklere göre farklılaşıp farklılaşmadığını incelemişlerdir (Kurt ve Yılmaz Alarçi, 2019). Bu çalışma Sağlık Bakanlığı tarafından yayınlanan kamu spotllarının sosyal pazarlama çerçevesinde temalaştırılması konusundadır.

Kamu spotları yerine getirmeyi amaçladığı hedefleri dikkate alındığında sosyal pazarlamanın önemli bir parçasını oluşturmaktadır. Geniş bir konu yelpazesine sahip olan kamu spotlarının genel çerçevesi yasal düzenlemelerle çizilmiştir. Çeşitli mecralarda yayınlanan kamu spotlarının insanlar üzerinde etkisi olduğu düşünülen kamu spotlarının içeriklerinin incelenmesi ilgili literatüre katkı sağlayacaktır (Zalluhoğlu, Karslı, Candemir, ve Günay, 2015, s.467).

\section{Sosyal Pazarlama}

Andreasen (1994) sosyal pazarlamayı "ticari pazarlama teknolojilerini kullanarak hedef kitlelerin gönüllü davranışlarını etkilemek için kişisel refahlarını 
ve bir parçası oldukları toplumu geliştirmek amacıyla yapılan uyarlamalar" olarak tanımlamaktadır (Andreasen, 1994: 110). Sosyal pazarlama, daha yaşanılabilir bir toplum yaratmak için kullanılan araçlardan biridir. Geleneksel pazarlama faaliyetlerinin aksine kar amaçlı uygulanmayıp toplumda hoş karşllanmayan diğer bir ifadeyle topluma zarar veren davranışların ortadan kaldırılmasında destek olmaktadır (Can, 2017: 23). Bu bağlamda ele alındığında pandemi sürecinde Sağlık Bakanlığı, insanları bilinçlendirmek ve salgının yayılımını önlemek hatta durdurmak amaciyla televizyon, sosyal medya ve çeşitli internet platformlarında hazırlatmış oldukları kamu spotlarının yayınlanmasını sağlamaktadır.

Tablo 1'de ticari pazarlama ile sosyal pazarlama arasındaki farklılıklar ve benzerlikler yer almaktadır.

Tablo 1. Ticari Pazarlama ile Sosyal Pazarlama Arasındaki Farklılklar ve Benzerlikler

\begin{tabular}{|c|c|c|}
\hline & Ticari Pazarlama & Sosyal Pazarlama \\
\hline \multirow{4}{*}{ Farklılıklar } & $\begin{array}{l}\text { Pazarlama sürecinin temelinde mal } \\
\text { veyahizmetin satılması bulunmaktadır. }\end{array}$ & $\begin{array}{l}\text { Pazarlama sürecinin temelinde istenen bir dav- } \\
\text { ranışı satmak yatmaktadır. }\end{array}$ \\
\hline & $\begin{array}{l}\text { Maddi kazanım sağlamak için yapıl- } \\
\text { maktadır. }\end{array}$ & $\begin{array}{l}\text { Bireysel ve toplumsal kazanımlar için yapıl- } \\
\text { maktadır. }\end{array}$ \\
\hline & $\begin{array}{l}\text { Hedef kitle seçilirken en karlı satı̧ı sağ- } \\
\text { layacak kitle belirlenir. }\end{array}$ & $\begin{array}{l}\text { Hedef kitle seçilirken farklı kriterler göz } \\
\text { önündebulundurularak yapılmaktadır. Sosyal } \\
\text { pazarlamada segmentler belirlenirken kullanı- } \\
\text { lan kriterlerden biri en fazla davranış değişikli- } \\
\text { ğine sebep olacak kitlenin seçilmesidir. }\end{array}$ \\
\hline & $\begin{array}{l}\text { Benzer mal ve hizmet sunan işletmeler } \\
\text { rakip olarak kabul edilmektedir. }\end{array}$ & $\begin{array}{l}\text { Rakip, davranışları sunan ya da teşvik eden } \\
\text { kuruluşlardır. Sosyal pazarlamada rekabet, he- } \\
\text { def kitlenin mevcut ya da özendirdiği davra- } \\
\text { nştır. Bu davranışarın algılanan faydaları ve } \\
\text { maliyetleri rekabet unsuru olarak kullanılmak- } \\
\text { tadır. }\end{array}$ \\
\hline Benzerlikler & $\begin{array}{l}\text { Hem ticari pazarlamada hem de sosyal } \\
\text { sağlayacak kitleye hitap etmeye çalışmal }\end{array}$ & $\begin{array}{l}\text { zarlamada pazarlamacılar en fazla geri dönüşü } \\
\text { adırlar. }\end{array}$ \\
\hline
\end{tabular}

Kotler ve Lee, 2010, s.99

Sağlık Bakanlığı'nın sunmuş olduğu koruyucu sağlık hizmetlerinin içerisinde tanıtım ve reklam (kamu spotları) önemli bir yer tutmaktadır. Sağlık Bakanlığı zaman zaman yürütülen bu faaliyetlerle koruyucu sağlık hizmetine olan ilgiyi artırmak hatta tedavi süreçlerinin bir parçası haline getirmeyi amaçlamaktadır (Gümüş ve Toy, 2013, s.95). Pandemi sürecinde Sağlık Bakanlığı, korona virüsün yayılımını azaltmak için koruyucu sağlık hizmetleri 
kapsamında kamu spotları ve alanda uzman sağlık çalışanlarının vermiş oldukları röportajlarla insanları bilinçlendirme faaliyetleri yürütmektedir. Bunlara ek olarak koruyucu sağlık hizmetleri kapsamında sigara kullanımını azaltmayı hedefleyen, insanların obezite konusunda bilinçlendiren ve aşı ile ilgili tereddütlerini gidermek için kampanyalar yapmaktadır.

\section{Sosyal Pazarlama Karması}

Ticari pazarlama anlayışında olduğu gibi sosyal pazarlama anlayışında da birincil odak noktasını tüketiciler oluşturmaktadır. İşletmelerin üretilen mal ve hizmetleri satmaya çalışmak yerine insanların nelere ihtiyaç duyduklarını ve ne istediklerini anlamaya çalışmaları gerekmektedir. Pazarlama faaliyetlerinde mal ve hizmetlerin değil müşterinin ön plana çıkarılmasının önemi artmaktadır. Pazarlama faaliyetlerinin planlama sürecinde pazarlama karması (4P) unsurlarını ele alarak tüketici odak noktaya alarak hesaba katması önem arz etmektedir. Ticari pazarlama faaliyetleri için kullanılan pazarlama karmasına ek olarak sosyal pazarlama için eklenmiş unsurlar bulunmaktadır (Weinreich, 2006). Sosyal pazarlama alaninda kullanılan pazarlama karması unsurları şunlardır:

Ürün (Product): Sosyal pazarlamada satılan sunulan ürün arzu eden davranış ve bu davranışın beraberinde gelen faydadır. Sosyal pazarlamada ürünün davranış değişikliğini destekleyebilmesi ve kolaylaştırması amacıyla mal ya da hizmetle beraber sunulduğu durumlar da bulunmaktadır (Eser ve Özdoğan, 2006, s.62).

Fiyat (Price): Sosyal pazarlamada planlanması önem arz eden değişkendir. Fiyatlandırma ürünü algılayış biçiminde ve sosyal ürünü elde etme durumunda en önemli belirleyiciler arasında yer almaktadır. Fiyat konusu pazarlama karması içerisinde önemli bir denge unsurudur (Nurtanış Velioğlu, ve Çoknaz, 2010, s.466). Sosyal pazarlamada fiyatın davranış değişikliği konusunda insanları ikna etme özelliği bulunmaktadır. Aslında fiyat, bu davranışa ikna olduğunda insanların katlanması gereken maliyet (diğer bir ifadeyle ücret)'tir.

Dă̆ıtım (Place): Sosyal pazarlamanın hedef kitlesi içerisinde yer alan istenilen davranışın gerçekleştirileceği ve bu davranış ile ilgili mal ve hizmetlerin 
alınacağ 1 yeri ifade etmektedir (Lee ve Kotler, 2020, s.12). Sosyal amaçlı bir ürünün kullanımının yaygınlaştırılmasına, pandemi sürecinde devletin ücretsiz maske dağıtması örnek olarak verilebilir. Bu örnek insanların salgından korunmalarını sağlayacak ekipmanlara kolaylıkla ulaşmalarını sağlamıştır. Koruyucu ekipmanlar eczanelerde, marketlerde ve diğer satış noktalarında insanların kolaylıkla ulaşabilmeleri için ücreti mukabilinde kullanıma sunulmuştur.

Tutundurma (Promotion): Sosyal pazarlamada pazarlama mesajları genellikle bir iletişim kanalı olan sosyal medya üzerinden verilmektedir (Boone,ve Kurtz, 2012, s.21). Sosyal medya, sosyal pazarlama stratejilerine yeni bir boyut kazandırmıştır. Sivil toplum kuruluşlarının sosyal medya üzerinden yapmış oldukları çalışmalar ofisi bulunmayan şehirlerdeki insanlara bile ulaşmalarını mümkün kılmıştır. Diğer bir ifadeyle sosyal medya erişim sorununun ortadan kaldırılmasını sağlamıştır (Can, 2017, s.42). Sosyal pazarlama faaliyetlerinde belirli grupların desteği alınarak faaliyetlerin etkisi artırılmaya ve genişletilmeye çalışılmaktadır. Sosyal pazarlamacılar daha iyi bir dünya için kendi çevrelerinde networkler oluşturmaktadırlar. Networkler ne kadar nitelikli ve güçlü olursa sosyal pazarlamanın etkisi artacaktır (Özer, 2020, s.27). Bu networklerin kurulmasını ve sosyal pazarlama faaliyetlerinde etkinliğin artırılması, kamu spotları vasıtasıyla sağlanmaktadır. Tutundurma, pazarlama faaliyetleri ile ilgili pazarlama mesajlarının verileceği mecraları ifade etmektedir.

Kamuoyu (Publics): Sosyal pazarlamacılar genellikle kampanyaların başarıyla tamamlanabilmesi için hem harici hem de dahili birçok kitleye hitap etmektedirler. Harici kamuoyunu; hedef kitle, ikincil hedef kitle ve politika yapıcılar oluştururken dahili kamuoyunu ise; kampanyanın onaylanması ve uygulanması konularına dahil olan kişiler oluşturmaktadır (Weinreich, 2006).

Ortakliklar (Partnership): Etkin sosyal pazarlama faaliyetlerinin oluşturulabilmesi için benzer hedeflere sahip organizasyonlarla ortaklıkların kurulmasını ifade etmektedir. Sosyal sorunlar ve sağlık sorunları karmaşık yapıda olduğu için genel olarak bir kurumun üstesinden gelmesi zordur (Weinreich, 
2006). Zaman ve parasal destek açısından sorun yaşayan kurum ve kuruluşlar potansiyel ortaklıklar oluşturmaya çalışmaktadırlar (Dinan ve Sargeant, 2000, s.6).

Politika (Policy): Sosyal pazarlama faaliyetleri bireysel davranış değişikliklerini motive etme konusunda başarılı olsa da bu davranışlar uzun vadede desteklenmediği sürece bu davranışların sürdürebilirliği zordur (Weinreich, 2006). Bireylerde istenilen davranış değişikliklerine ulaştırmanın tek yolu bireyi istenilen davranış değişikliğine zorlamaktır (Dinan \& Sargeant, 2000: 6). Sosyal pazarlama ile ilgili uygulanacak politikaları kapsamaktadır.

Fon Sağlayıcılar: Para Kontrolï (Purse String): Sosyal pazarlama faaliyetinde bulunan kurum ve kuruluşların çoğu, faaliyetlerde kullanacakları fonları vakıflardan, devlet katkılarından ve bağışlardan sağlamaktadır (Weinreich, 2006).

Tablo 2' de koruyucu sağlık hizmetleri kapsamında sosyal pazarlama faaliyetlerinde kullanılan pazarlama karması unsurları pandemi sürecine uyarlanarak verilmiştir.

Tablo 2. Pandemi Sürecinde Yapılan Sosyal Pazarlama Faaliyetlerinde Pazarlama Karması Unsurları

\begin{tabular}{|c|c|}
\hline $\begin{array}{l}\text { Pazarlama } \\
\text { Karması }\end{array}$ & Pandemi Sürecinde Sosyal Pazarlama Faaliyetlerinde Pazarlama Karması Unsurları \\
\hline Ürün & $\begin{array}{l}\text { - Salgınla ilgili belirtiler olduğunda test yaptırmak, } \\
\text { - Maske, eldiven gibi koruyucu ekipman kullanımı yaygınlaştırmak, } \\
\text { - Sosyal mesafeye bulunulan tüm ortamlarda uyulmasını ve } \\
\text { - Günlük hayatta hijyen şartlarına dikkat edilmesini sağlamaktır. } \\
\text { (Genelde kamu spotlarında Maske-Mesafe-Temizlik olarak kullanılmıştır.) }\end{array}$ \\
\hline Fiyat & $\begin{array}{l}\text { - Virüsten korunma için kullanılan ekipman ücretleri, } \\
\text { - Virüsün bulaştı̆̆ı kşilerin bakım ücretleri, } \\
\text { - Virüsün varlı̆ını tespitte kullanılan test ücretleri, } \\
\text { (İki test çeşidi bulunmaktadır. Bunlar; PCR (virüsün vücutta varlı̆ını moleküler düzeyde } \\
\text { ortaya koymak için yapılan test güvenilirliği yüksek olsa da fiyatı yüksektir.) ve hızlı test } \\
\text { (Kart test) (virüsün vücutta varlı̆ııı kanda antikor ve antijenlerle aramaya yarayan hızlı } \\
\text { sonuç veren bir testtir. Fiyatı PCR'ye göre daha uygun olsa da sonuçlarının güvenilirliği } \\
\text { düşüktür.)) } \\
\text { Kamu hastanelerinde bakım ve testler ücretsiz olarak uygulansa da özel hastanelerde ba- } \\
\text { kım ve test ücretleri için ciddi meblağlar talep edilmektedir. } \\
\text { - Koruyucu ekipman ücretleridir. } \\
\text { (Pandemi sürecinin başlarında maskeye olan talebin artması maske fiyatlarını da fiyatlar } \\
\text { artmıştır. Bunun üzerine devlet maske fiyatlarına tavan fiyat uygulamaya başlamış̧tır.) }\end{array}$ \\
\hline Dağtım & $\begin{array}{l}\text { - Kamu hastaneleri ve Özel hastaneler, } \\
\text { - Koruyucu ekipman dağıtımına ve satışına destek olan kurum ve kuruluşlardır. }\end{array}$ \\
\hline
\end{tabular}




\begin{tabular}{|c|c|}
\hline $\begin{array}{l}\text { Tutun- } \\
\text { durma }\end{array}$ & $\begin{array}{l}\text { - Alanda uzman sağlık çalışanlarının vermiş oldukları röportajlar, } \\
\text { - Sağlık Bakanlığı'nın desteği ile oluşturulup çeşitli mecralarda yayınlanan kamu spotları, } \\
\text { - Pandeminin başında insanların dikkatlerini çekmek ve virüsün yayılımını azaltmaları ko- } \\
\text { nusunda duyarlılık kazanmalarını sağlamak için devletin ücretsiz maske dağıtması verile- } \\
\text { bilecek örnekler arasında yer almaktadır. }\end{array}$ \\
\hline Kamuoyu & - Virüsün yayılımına sebep olan ve virüsle mücadele eden herkes \\
\hline Ortaklık & $\begin{array}{l}\text { - Virüsün yayılımını engellemeye çalışan ulusal ve uluslararası sağlık örgütleri, } \\
\text { - Koruyucu ekipmanların ve aşıların üretilmesini ve dağıtılmasını sağlayan ulusal ve ulus- } \\
\text { lararası örgütlerdir. }\end{array}$ \\
\hline Politika & $\begin{array}{l}\text { - Virüsle mücadele için bütçelerin ayrılarak virüsün yayılımını azaltacak tedbirlerin alın- } \\
\text { masını, } \\
\text { - Kamu kurum ve kuruluşları tarafından virüsle mücadelede kullanılacak politikaların ge- } \\
\text { liştirilmesini ve } \\
\text { - Özel kuruluşlar tarafından virüsle mücadelede kullanılacak politikaların geliştirilmesini } \\
\text { kapsamaktadır. }\end{array}$ \\
\hline $\begin{array}{l}\text { Fon } \\
\text { Sağlayıc1- } \\
\text { lar }\end{array}$ & $\begin{array}{l}\text { - Virüsün yayılımının durdurulması için araştırma yapan kişi, kurum ve kuruluşlara veri- } \\
\text { lecek katkıyı ifade etmektedir. Devlet katkılarını ve bağışları kapsamaktadır. } \\
\text { (Aşı çalışmaları devlet tarafından ve özel kuruluşlar tarafından fonlar ve hibelerle destek- } \\
\text { lenmektedir.) }\end{array}$ \\
\hline
\end{tabular}

\section{Kamu Spotlan}

Sosyal pazarlama aracı olarak kullanılan kamu spotları insanlarda davranış değişikliği beklentisiyle yapılan çalışmaları ifade etmektedir. Kamu spotlarının esas amac1; genelde radyo, televizyon mecrasını kullanarak insanların bilinçlendirilmesini sağlamaktır (Gençoğlu, Bağlıtaş, ve Kuşkaya, 2017, s.622). Günümüzde kamu spotları ve zorunlu yayınlar kamu ve özel radyo televizyon kanallarında yoğun olarak kullanılmaktadır (Bilgiç, 2016, s.25). Kamu spotu kampanyaları, genel olarak toplumun sosyal hayatını, sağlığını ve refahını tehdit eden durumlarda koruyucu önlemler almak için kullanılmaktadır. Bu kampanyalarla genelde korku uyarılması ve algılanan tehdit temalarını kullanarak insanlardaki karar alma süreçlerine etki edilmesi hedeflenmektedir (Ruiter, Abraham, ve Kok, 2001, s.613).

Kamu spotları özellikle sağlık alanında insanların hayatlarını tehdit eden konularda ve insanları yanlış tutum ve davranışlardan uzaklaştırarak istenilen davranışlara yönelmelerinde kullanılan önemli bir araçtır (Kurt, ve Yılmaz Alarçi, 2019, s.364). Özellikle pandemi döneminde insanları bilinçlendirerek salgının yayılımını azaltmak için kamu spotları çeşitli mecralarda yayınlanmakta ve yoğun olarak kullanılmaktadır. 


\section{Yöntem}

İçerik analizi nitel çerçevede dergi, gazete, video gibi çalışamaya konu olacak tüm materyallerin genel çerçevede değerlendirlmesi ve bu material içeriklerinin kavramsallaştırılmasında kullanılmaktadır. Buradaki kavramsallaştırmadan kasit ilgili materyalde verilmek istenen mesajin tema olarak ortaya konulmasıdır. Pandemi sürecinde yayınlanmış olan 34 kamu spotunun nitel araştırma yöntemleri arasında yer alan içerik analizi ile temalaştırılması ile ilgilidir.

Çalışmada kullanılan 34 kamu spotu çalışmaya başlandığında sağlık bakanlığının sitesinde yer alan videolardır. Sadece Sağlık bakanlığının pandemi sürecinde yayınlamış olduğu videoların kullanılması çalışmanın kısıtları arasında yer almaktadır. Diğer bir kısıt çalışmaya bilim kurulu üyelerinin yer aldığı ropörtaj kamu spotlarının eklenmemiş olmasıdır.

Çalışmada ortaya konulan kod ve alt kodların açık ve anlaşılır bir şekilde oluşturulması güvenilirlik ve inandırıcılık konusunda çalışmaya destek olmaktadır. Ayrıca kodve alt kodların çerçevesi çizilerek temaların bu kodlara göre oluşturulması geçerlilik konusunda çalışamyı desteklemektedir.

Çalışma sonucunda ortaya çıkan temalar sonraki dönemde yapılacak çalışmaların bu temalar ekseninde şekillendirilmesi konusunda literatüre katkı yapacağı düşünülmektedir. Çalışma kapsamında kullanılan videolar Sağlık Bakanlığı'nın ilgili sayfasından temin edilerek kullanılmıştır.

Çalışmanın amacı; Sağlık Bakanlığı' nın desteği ile hazırlanmış kamu spotlarının pandemi sürecinin yönetilmesinde insanları bilinçlendirmek, salgının yayılımını azaltarak durdurmak için çeşitli mecralarda yayınlanan kamu spotlarının sosyal pazarlama bağlamında temalaştırılmasını sağlamaktır.

Çalışma için Muş Alparslan Üniversitesi Bilimsel Araştırma ve Yayın Etiği Kurulu'na başvurulmuştur. Kurulun 29/05/2020 tarihli ve E.6011 sayılı toplantısında alınan 6 numaralı kararınca uygun bulunmuştur. Ayrıca ilgili videoların çalışma kapsamında kullanılabilmesi için Sağlık Bakanlığı'ndan izin alınmıştır.

\section{Bulgular}

Araştırma problemine açıklık getirmesi adına incelenen pandemi sürecinde Sağlık Bakanlığı tarafından yayınlanmış kamu spotlarının içeriklerinden elde 
edilen bulgular bu başlık altında sunulmuştur. Toplamda dış sesin oluşturduğu 34 video incelenmiştir. Videolar V1'den V34'e kadar kodlanmıştır. Çalışma Şekil 1'de görüldüğü üzere kamu spotlarıyla verilmek istenen mesajlar 3 ana tema altında toplanmıştır. Bu temalar; davranış kazandırma, farkındalik ve ikna etme' dir.

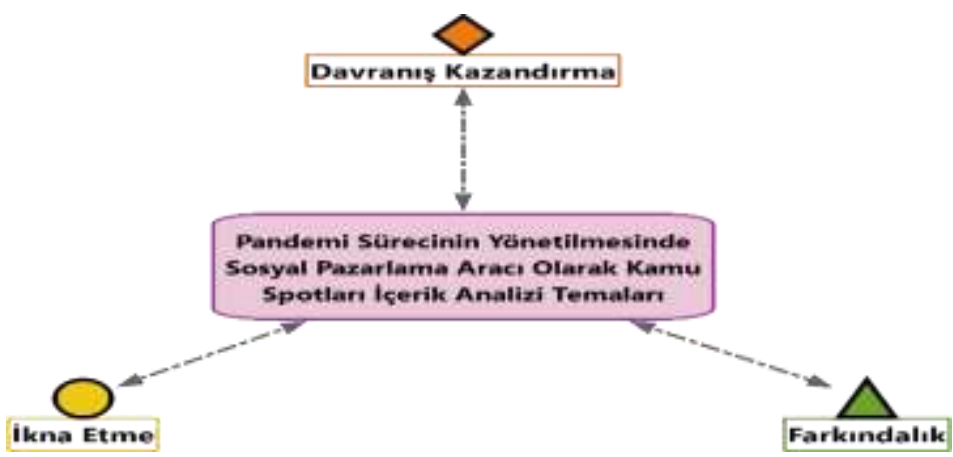

Şekil 1. Pandemi Sürecinin Yönetilmesinde Sosyal Pazarlama Aracı Olarak Kamu Spotları Tema Gösterimi

\section{Davranış Kazandırma Temasına İlişkin Bulgular}

Araştırmanın ilk teması olan davranış kazandırma teması hiyerarşik kod alt kod bölümler modeli Şekil 2' de görülmektedir. Davranış kazandırma teması altında korunmaya yönelik alınan tedbirler ile ilgili olan videolardan oluşturulan kodlar yer almaktadır.

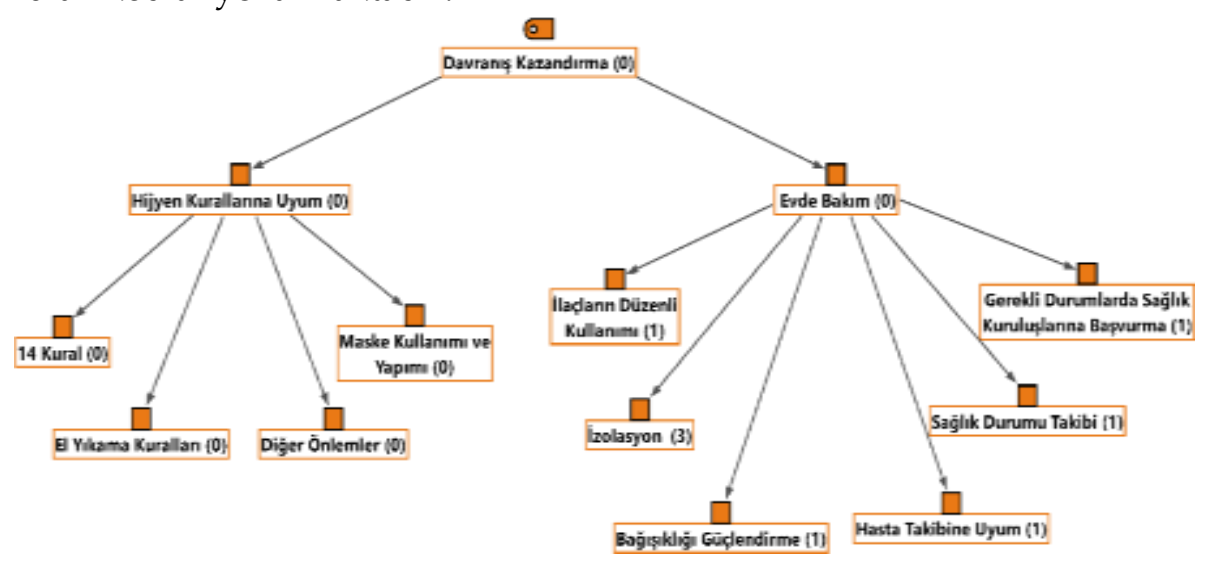

Şekil 2. Davranış Kazandırma Teması Hiyerarşik Kod-Alt Kod Bölümler Modeli 


\section{Hijyen Kurallarna Uyum Alt Koduna İlişkin Bulgular}

Davranış kazandırma temasının birinci kategorisi olan hijyen kurallarına uyum kategorisi; 14 kural, maske kullanımı ve yapımı, el yıkama kuralları ve diğer önlemler olarak kodlara ayrılmıştır.

a) 14 Kural: Birinci kategori olan hijyen kurallarına uyum kategorisinde yer alan kodlar kendi içlerinde alt kodlara ayrılmıştır. Alt kodlardan birinci olan 14 kural koduna ait alt kodlar Şekil 3'te görülmektedir. 14 kural kodu ile ilgili kodlar izlenen videolardan ortaya çıkarılmıştır. Bu kodlar; öksürme-hapşırma önlemleri, eller ile yüze temas etmeme, sosyal mesafe, fiziksel temastan kaçınma, maske kullanımı, elleri yıkama, havalandırma, sık kullanılan yüzeylerin temizlenmesi, kişisel eşyaların ortak kullanılmaması, kıyafetlerin 60-90 derecede yıkanması, bağışıklı̆gı güçlendirme, belirtiler var ise sağlık kuruluşuna başvurma, yurtdışı seyahatlerini iptal etme ya da erteleme ve yurtdışı dönüşlerinde ilk 14 gün ev izolasyonu kodlaridır.

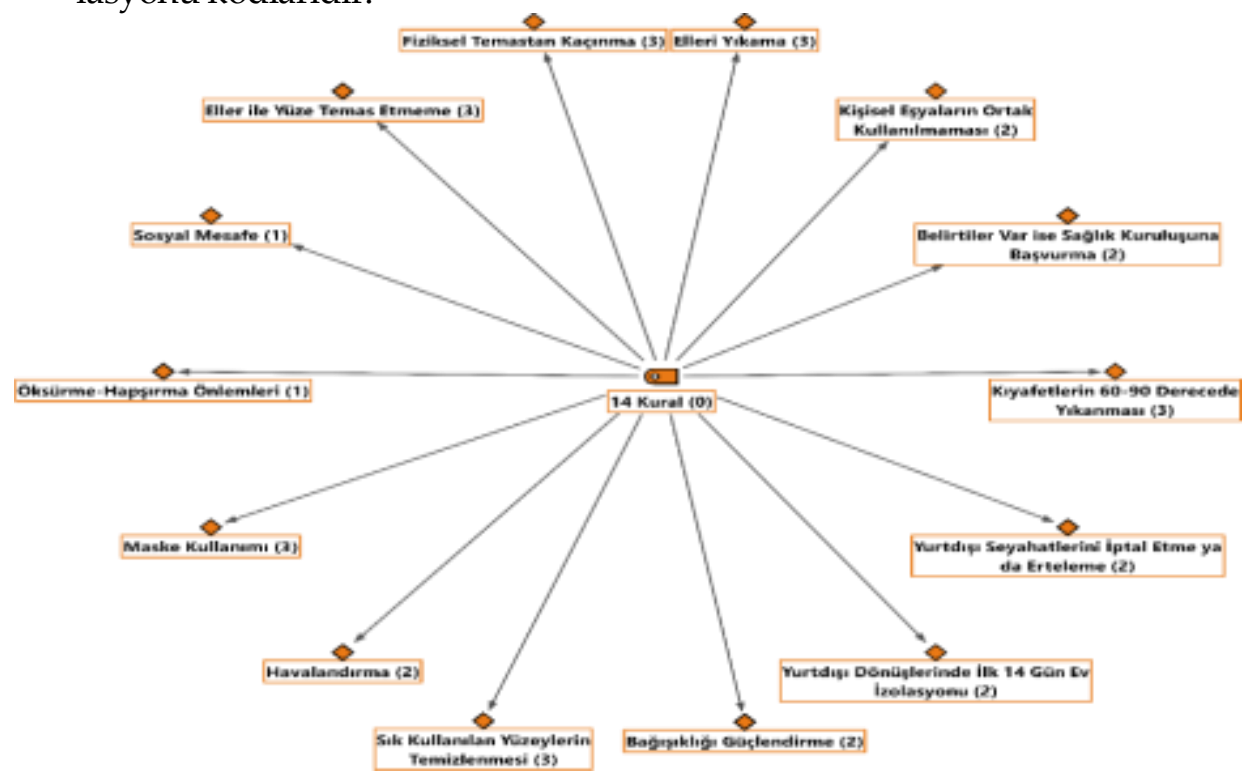

Şekil 3.14 Kural Kategorisine Ait Kod-Alt Kod Bölümler Modeli

14 kural kategorisinin oluşturulmasında, V1, V4, V5, V6 ve V24 kodlu 5 adet diş sese ait video kullanılmıştır. Videolardan elde edilen bulgulara göre, 
eller ile yüze temas etmeme, elleri yıkama, sık kullanılan yüzeylerin temizlenmesi, kıyafetlerin 60-90 derecede yıkanması kodları 3 videoda, havalandırma, maske kullanımı, kişisel eşyaların ortak kullanılması, fiziksel temastan kaçınma, bağışıklığı güçlendirme, belirtiler var ise sağlık kuruluşuna başvurma, yurtdışı seyahatlerini iptal etme ya da erteleme, yurtdışı dönüşlerinde ilk 14 gün ev izolasyon kodları 2 videoda, sosyal mesafe ve öksürmehapşırma önlemleri 1 videoda ifade edilmiştir.

b) El Yıkama Kuralları: Birinci kategori olan hijyen kurallarına uyum kategorisinde yer alan kodlar kendi içlerinde alt kodlara ayrılmıştır. Alt kodlardan üçüncüsü olan el yıkama kuralları koduna ait alt kodlar Şekil 4'te görülmektedir.

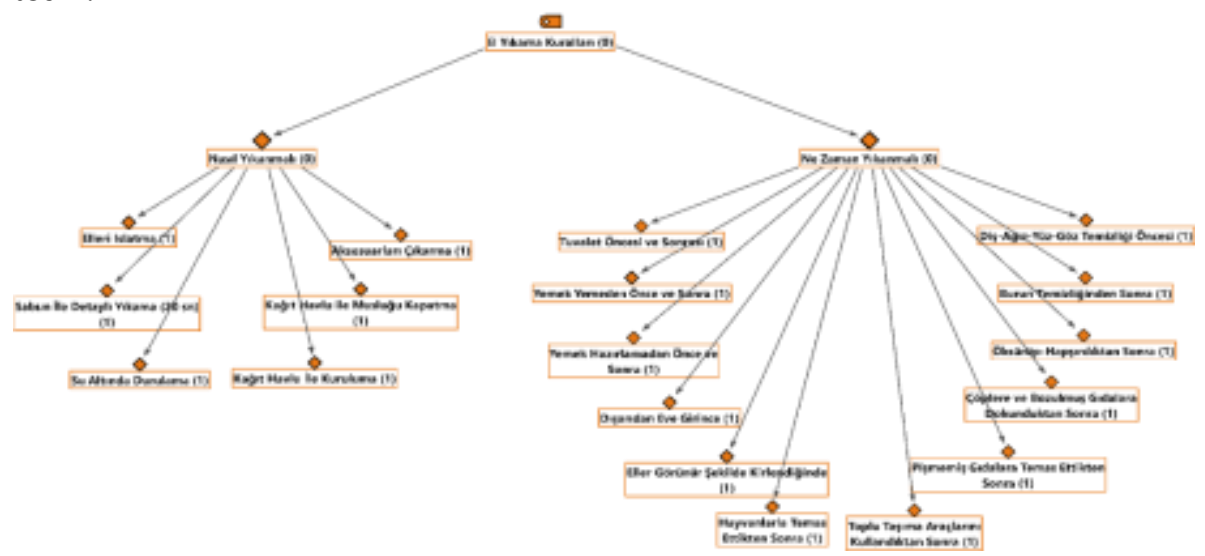

Şekil 4. El Yıkama Kurallan Kategorisine Ait Kod-Alt Kod Bölümler Modeli

El yıkama kuralları kategorisinin oluşturulmasında 2 adet dış sese ait video kullanılmıştır. El yıkama kuralları kategorisi nasıl yıkanmalı ve ne zaman yıkanmalı olarak iki koda ayrılmıştır.

b1) Nasıl Yikanmalı: Nasıl yıkanmalı kodunda 6 adet alt kod yer almaktadır. Bunlar; aksesuarları çıkarma, elleri ıslatma, sabun ile detaylı yıkama (20 sn), su altında durulama, kağıt havlu ile kurulama ve kağıt havlu ile musluğu kapatma kodlarıdır. Nasıl yıkanmalı kodunun alt kodları V2 kodlu videoda yer alan ifadeler ile oluşturulmuştur. V2 kodlu videoda dış ses yerine arka fonda müzik kullanılmış ve tıbbi maske kullanım yönergeleri yazılı olarak verilmiştir. 
b2) Ne Zaman Yikanmalı: Ne zaman yıkanmalı kodunda 12 adet alt kod yer almaktadır. Bunlar; dışarıdan eve girince, eller görünür şekilde kirlendiğinde, hayvanlarla temas ettikten sonra, toplu aşıma araçlarını kullandıktan sonra, pişmemiş gıdalarla temas ettikten sonra, çöplere ve bozulmuş gıdalara dokunduktan sonra, öksürüp-hapşırdıktan sonra, burun temizliğinden sonra, diş-ağı-yüz-göz temizliği öncesi, tuvalet öncesi ve sonrası, yemek yemeden önce ve sonra ve yemek hazırlamadan önce ve sonra kodlarıdır. Ne zaman yıkanmalı kodunun alt kodları V3 kodlu videoda yer alan ifadeler ile oluşturulmuştur. V3 kodlu videoda dış ses yerine arka fonda müzik kullanılmış ve tıbbi maske kullanım yönergeleri yazılı olarak verilmiştir. Videolardan elde edilen bulgulara göre, nasıl yıkanmalı ile ilgili kodlar ve ne zaman yıkanmalı ile ilgili kodlar birer videoda ifade edilmiştir.

c) Diğer Önlemler: Birinci kategori olan hijyen kurallarına uyum kategorisinde yer alan kodlar kendi içlerinde alt kodlara ayrılmıştır. Alt kodlardan sonuncusu olan diğer önlemler koduna ait alt kodlar Şekil 5'te görülmektedir.

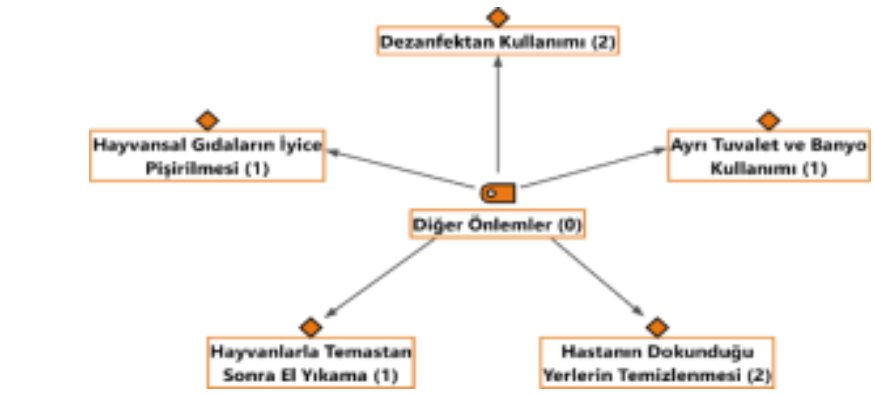

Şekil 5. Diğer Önlemler Kategorisine Ait Kod-Alt Kod Bölümler Modeli

Diğer önlemler kategorisinde; hayvanlarla temastan kaçınma, hayvansal g1daların iyice pişirilmesi, dezenfektan kullanımı, hastanın dokunduğu yerlerin temizlenmesi ve ayrı tuvalet ve banyo kullanımı kodları yer almaktadır. Diğer önlemler kategorisinin oluşturulmasında V1 ve V24 kodlu 2 adet diş sese ait video kullanılmıştır. Videolardan elde edilen bulgulara göre, dezenfektan kullanımı kodu iki videoda, diğer kodlar ise bir videoda ifade edilmiştir. 
d) Maske Kullanımı ve Yapımı: Birinci kategori olan hijyen kurallarına uyum kategorisinde yer alan kodlar kendi içlerinde alt kodlara ayrılmıştır. Alt kodlardan ikincisi olan maske kullanımı ve yapımı koduna ait alt kodlar Şekil 6 'da görülmektedir.

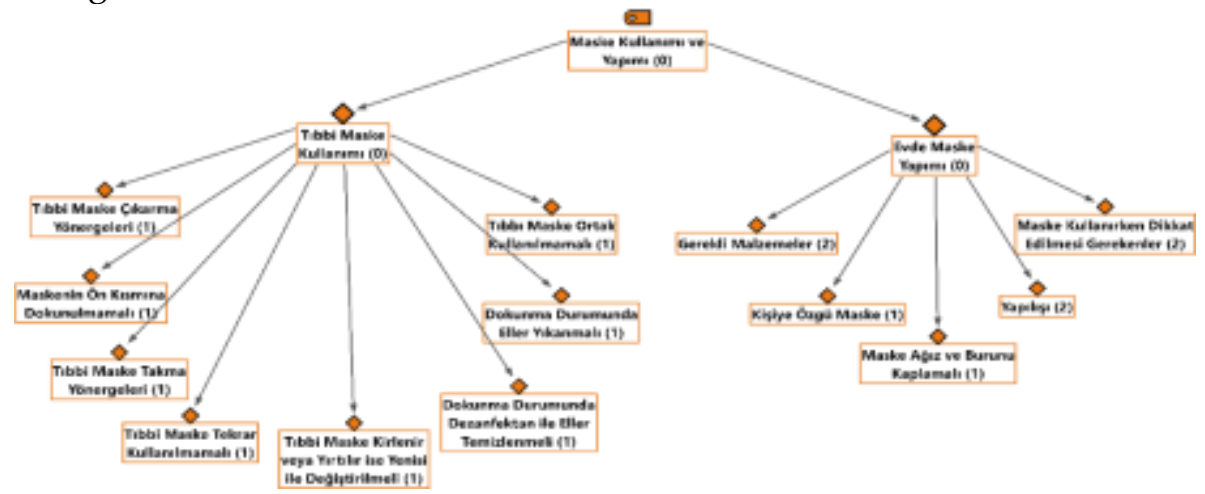

Şekil 6. Maske Kullanımı ve Yapımı Kategorisine Ait Kod-Alt Kod Bölümler Modeli

Maske kullanımı ve yapımı kategorisinin oluşturulmasında 4 adet dış sese ait video kullanılmıştır. Tıbbi maske kullanımı ve yapımı kategorisi tıbbi maske kullanımı ve evde maske yapımı olarak iki koda ayrılmışır

d1) Tibbi Maske Kullanımı: T1bbi maske kullanımı kodunda 8 adet alt kod yer almaktadır. Bunlar; tıbbi maske takma yönergeleri, tıbbi maske çıkarma yönergeleri, tıbbi maske tekrar kullanılmamalı, tıbbı maske ortak kullanılmamalı, tıbbi maske kirlenir veya yırtılır ise yenisi ile değiştirilmeli, dokunma durumunda dezenfektan ile eller temizlenmeli, maskenin ön kısmına dokunulmamalı ve dokunma durumunda eller yıkanmalı kodlarıdır. Tıbbi maske kullanımı kodunun alt kodları V7 kodlu videoda yer alan ifadeler ile oluşturulmuş̧tur. V7 kodlu video'da diş ses yerine arka fonda müzik kullanılmış ve tıbbi maske kullanım yönergeleri yazılı olarak verilmiştir.

d2) Evde Maske Yapımı: Evde maske yapımı kodunda 5 adet alt kod yer almaktadır. Bunlar; maske ağız ve burunu kaplamalı, kişiye özgü maske, maske kullanırken dikkat edilmesi gerekenler, yapılışı ve gerekli malzemeler kodlarıdır. Evde maske yapımı kodunun alt kodları V9, V10, V11 kodlu videolarda yer alan ifadeler ile oluşturulmuştur. Videolardan elde edilen bulgulara göre, evde maske yapımı ile ilgili kodlar üç videoda ifade edilirken, tıbbi maske kullanımı kodları bir videoda ifade edilmiştir. 


\section{Evde Bakım Alt Koduna İlişkin Bulgular}

Davranış kazandırma temasının ikinci kategori olan evde bakım kategorisi; ilaçların düzenli kullanımı, izolasyon, bağışıklığı güçlendirme, hasta takibine uyum, sağlık durumu takibi, gerekli durumlarda sağlık kuruluşlarına başvurma olarak kodlara ayrılmıştır.

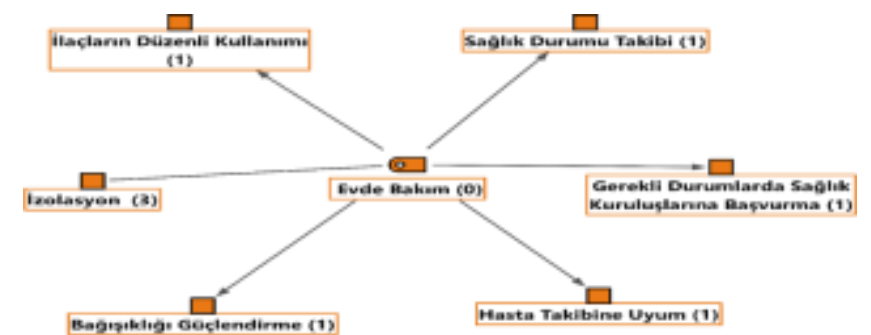

Şekil 7. Evde Bakım Kategorisine Ait Kod-Alt Kod Bölümler Modeli

Evde bakım kategorisi V24 kodlu videoda yer alan ifadeler doğrultusunda oluşturulmuştur. V24 kodlu videoda diş ses yerine arka fonda müzik kullanılmış ve evde bakım yönergeleri yazılı olarak verilmiştir.

\section{Farkındalık Temasına İlişkin Bulgular}

Araştırmanın ikinci teması olan farkındalık teması hiyerarşik kod alt kod bölümler modeli Şekil 8'de görülmektedir. Farkındalık teması altında genel bilgilendirme ve sigara kullanımı ile ilgili olan videolardan oluşturulan kodlar yer almaktadır.

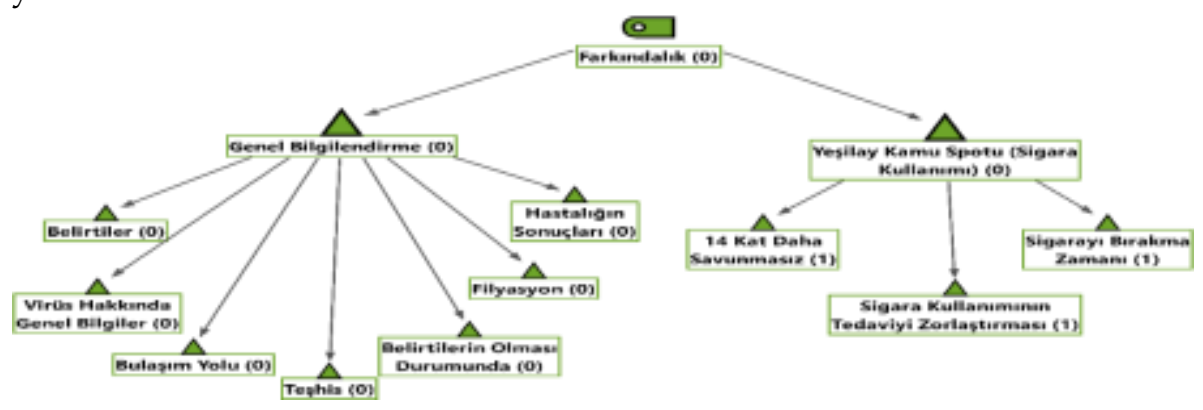

Şekil 8: Farkındalık Teması Hiyerarşik Kod-Alt Kod Bölümler Modeli 


\section{Genel Bilgilendirme}

Farkındalık temasının ilk kategorisi olan genel bilgilendirme kategorisi virüs hakkında belirtiler, virüs hakkında genel bilgiler, bulaşım yolu, teşhis, belirtilerin olması durumu, filyasyon ve hastalığın sonuçları olarak kodlara ayrılmıştır. Ayrıca farkındalık temasının ilk kategorisi olan genel bilgilendirme kategorisinde yer alan kodlar kendi içlerinde alt kodlara ayrılmıştır.

a) Belirtiler: Diğer bir alt kod olan belirtiler kodunda 5 adet alt kod yer almaktadır. Şekil 9'da ye alan belirtiler kodunun alt kodlarl; ateş, öksürük, nefes darlığı, zatürre ve böbrek yetmezliği kodlarıdır.

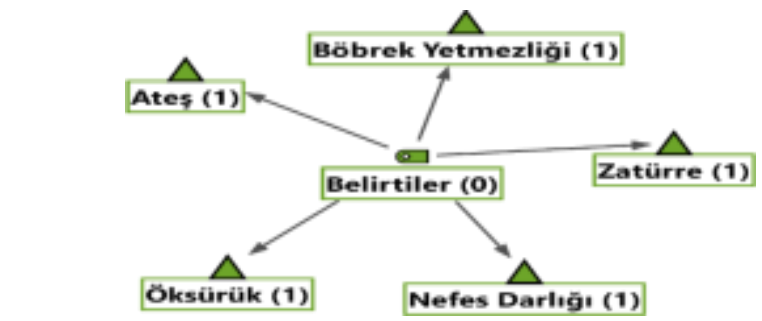

Şekil 9. Belirtiler Kategorisine ait Kod-Alt Kod Bölümler Modeli

Belirtiler kodunun oluşturulmasında, V1 kodlu dış sese ait video kullanılmıştır.

b) Virüs Hakkında Genel Bilgi: Alt kodlardan ilki olan virüs hakkında genel bilgi kodunda 9 adet alt kod yer almaktadır. Şekil 10'da yer alan virüs hakkında genel bilgiler kodunun alt kodları; virüsün çıkış noktası, büyük bir virüs ailesi, virüsün kökeni, virüsün şekli, virüsün değişkenlik göstermesi, isimlendirme, etken virüs farklılığı, bilgiye ulaşım kanalları (sosyal medya, web site) ve şikâyetin dinlenmesi ve çözüm üretilmesi (SABIM) kodlarıdır. 


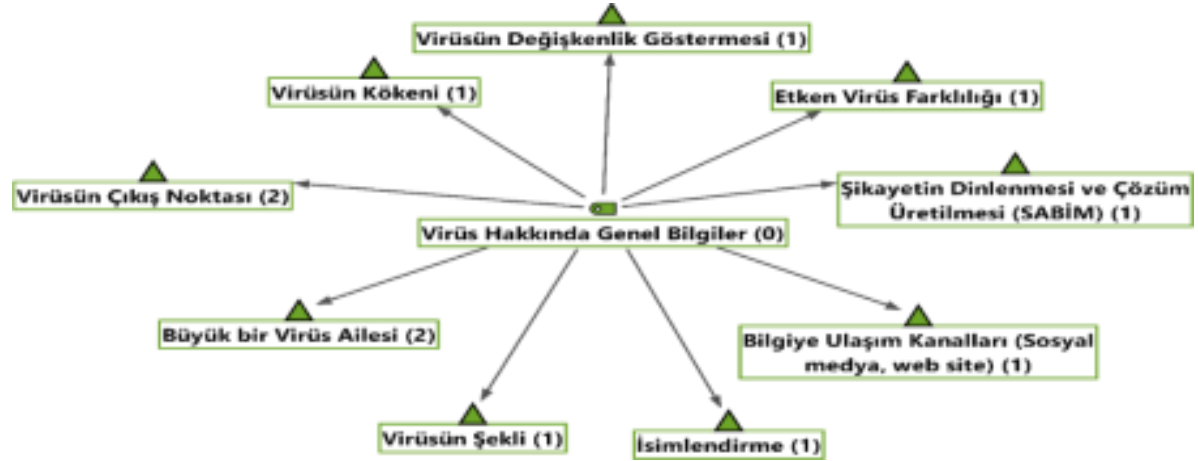

Şekil 10. Virüs Hakkında Genel Bilgiler Kategorisine ait Kod-Alt Kod Bölümler Modeli

Virüs hakkında genel bilgiler kodunun oluşturulmasında, V1 ve V25 kodlu 2 adet dış sese ait video kullanılmıştır.

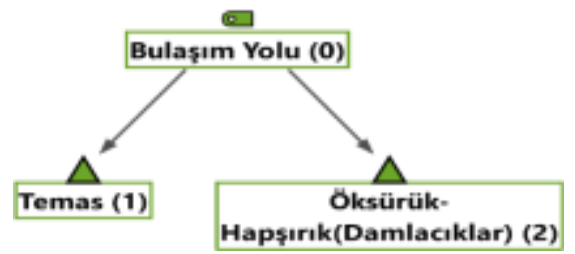

Şekil 11. Bulaşım Yolu Kategorisine ait Kod-Alt Kod Bölümler Modeli

Bulaşım yolu kodunun oluşturulmasında, V1 ve V4 kodlu 2 adet diş sese ait video kullanılmıştır. V4 kodlu video arka fonda müzik ile yazı şeklinde verilmiştir.

d) Teşhis: Diğger bir alt kod olan teşhis kodunda 1 adet alt kod yer almaktadır. Şekil 12' de ye alan teşhis kodunun alt kodu; PCR (Polimeraz Zincir Reaksiyon, Genetik Parmak izi) kodudur.

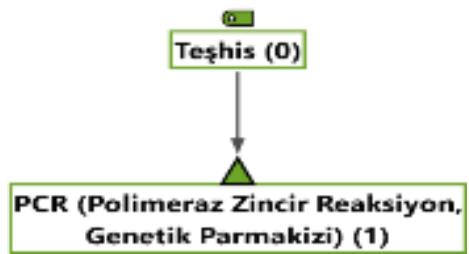

Şekil 12. Teşhis Kategorisine Ait Kod-Alt Kod Bölümler Modeli

Teşhis kodunun oluşturulmasında, V1 kodlu dış sese ait video kullanılmıştır. 
e) Belirtilerin Olması Durumunda: Genel bilgilendirme kategorisinin diğer bir kodu olan belirtilerin olması durumunda kodunda 3 adet alt kod yer almaktadır. Şekil 13'te yer alan belirtilerin olması durumunda kodunun alt kodları; seyahat geçmişini paylaşma, sağlık kuruluşuna gitme ve evde dinlenme kodlandır. Belirtilerin olması durumunda kodunun oluşturulmasında, V1 kodlu dış sese ait video kullanılmıştır.

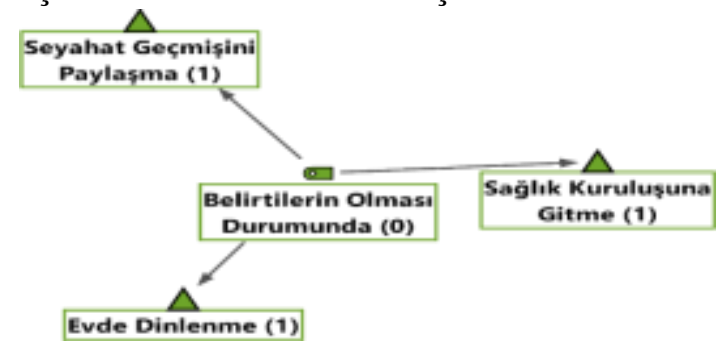

Şekil 13. Belirtilerin Olması Durumunda Kategorisine Ait Kod-Alt kod Bölümler Modeli

f) Filyasyon: Genel bilgilendirme kategorisinin son kodu olan filyasyon kodunda 11 adet alt kod yer almaktadır. Şekil 14'te yer alan filyasyon kodunun alt kodları; istatistiki sonuçların takibi, vaka takibi, en yaygın kullanım oranı (Türkiye), erken tanı ve tedavi, yeni bulaş zincirlerinin engellenmesi, test sonuçlarına göre tedavi veya izlem, temaslıların uzman ekip tarafından ziyaret edilmesi, temaslıların bilgisinin sisteme eklenmesi, temaslıların taranması, temaslıların taranması ve kaynağın erken saptanması kodlarıdır. Filyasyon kodunun oluşturulmasında, V23 kodlu diş sese ait video kullanılmıştır.

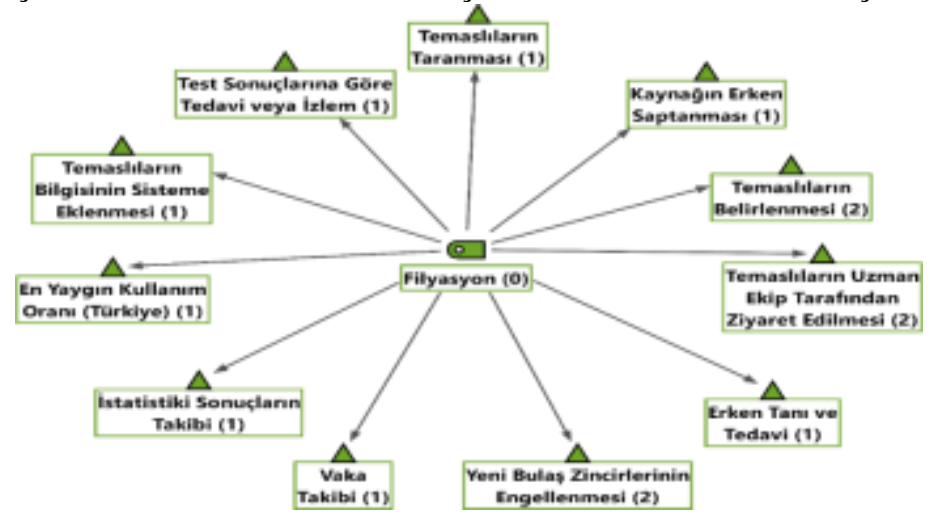

Şekil 14. Filyasyon Kategorisine Ait Kod-Alt Kod Bölümler Modeli 
Videolardan elde edilen bulgulara göre, virüs hakkında genel bilgiler ve bulaşım yolu kodları 2 videoda, belirtiler, teşhis, belirtilerin olması durumunda, hastalığın sonuçları ve filyasyon kodları ise bir videoda ifade edilmiştir.

g) Hastalı̆̆ın Sonuçlarn: Genel bilgilendirme kategorisinin diğer bir kodu olan hastalığın sonuçları kodunda 2 adet alt kod yer almaktadır. Şekil 15'te yer alan hastalığın sonuçları kodunun alt kodları; sindirim sistemi hastalıkları ve solunum sistemi hastalıkları kodlarıdır.

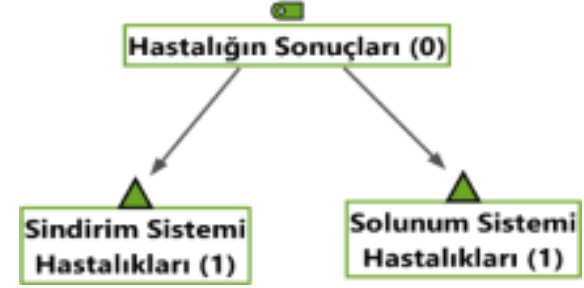

Şekil 15. Hastalığın Sonuçlan Kategorisine Ait Kod-Alt Kod Bölümler Modeli

Hastalığın sonuçları kodunun oluşturulmasında, V1 kodlu dış sese ait video kullanılmıştır.

\section{Yeşilay Kamu Spotu (Sigara Kullanımı)}

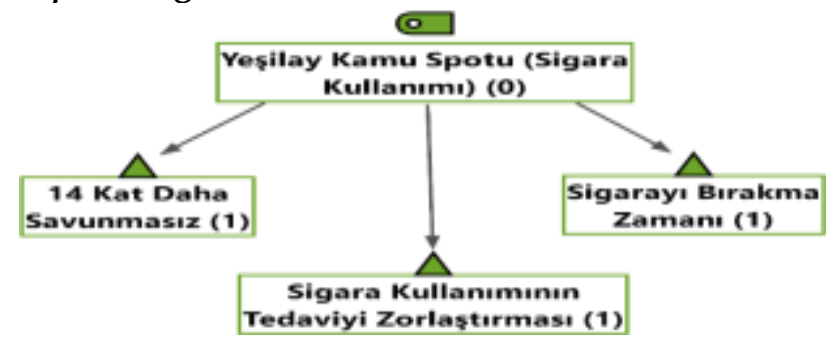

Şekil 16. Yeşilay Kamu Spotu (Sigara Kullanımı) Kategorisine Ait Kod-Alt Kod Bölümler Modeli

Yeşilay kamu spotu (sigara kullanımı) kategorisinin oluşturulmasında, V8 kodlu diş sese ait video kullanılmıştır. Videolardan elde edilen bulgulara göre, sigarayı bırakma zamanı, sigara kullanımının tedaviyi zorlaştırması ve 14 kat daha savunması kodları bir videoda ifade edilmiştir. 


\section{İkna Etme Temasına İlişkin Bulgular}

Araştırmanın üçüncü teması olan ikna etme teması hiyerarşik kod alt kod bölümler modeli Şekil 17'de görülmektedir. İkna etme teması altında riski görün, birlikte yeneceğiz ve hayat eve sığar kategorileri ile ilgili olan videolardan oluşturulan kodlar yer almaktadır.

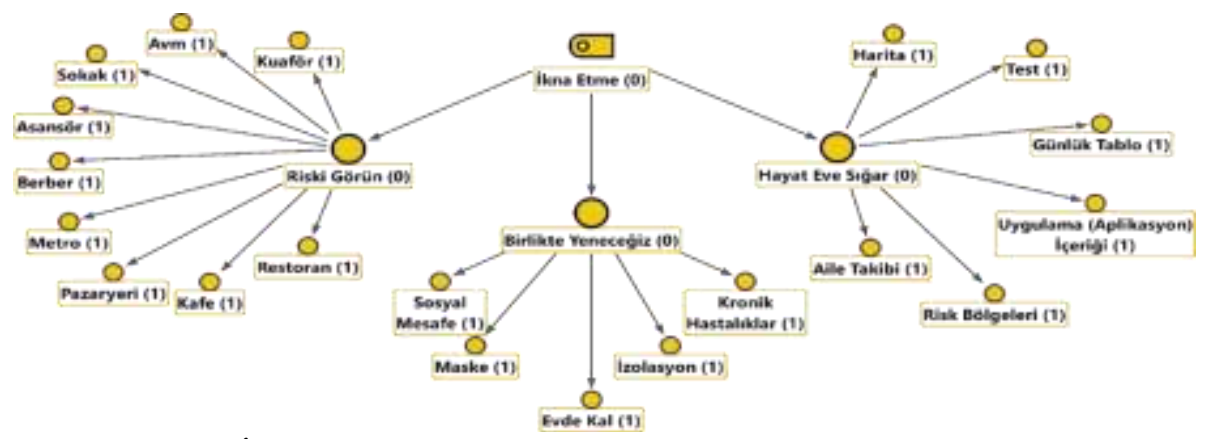

Şekil 17. İkna Etme Teması Hiyerarşik Kod-Alt Kod Bölümler Modeli

a) Riski Görün: İkna etme temasının ilk kategorisi olan riski görün kategorisinde 9 adet kod yer almaktadır. Riski görün kategorisinin kodları; kuaför, AVM, sokak, asansör, berber, metro, pazaryeri, kafe ve restoran kodlarıdır. Riski görün kategorisinin oluşturulmasında, V26, V27, V28, V29, V30, V31, V32, V33 ve V34 kodlu dış sese ait videolar kullanılmıştır. Kullanılan tüm "riski görün" temalı videolarda aynı dış ses ifadeleri kullanmıştır. Videolarda yalnızca görseller kodlara göre değişmektedir.

b) Birlikte Yeneceğiz: İkna etme temasının ikinci kategorisi olan birlikte yeneceğiz kategorisinde 5 kod yer almaktadır. Birlikte yeneceğiz kategorisinin kodlarl; sosyal mesafe, maske, evde kal, izolasyon ve kronik hastalıklar kodlarıdır. Birlikte yeneceğiz kodlarının oluşturulmasında V12, V13, V14, V15 ve V16 kodlu dış sese ait videolar kullanılmıştır. Videolarda dikkat çekici unsur olarak sağlık çalışanlarının yüzleri kullanılmıştır.

c) Hayat Eve Sığar: İkna etme temasının son kategorisi olan hayat eve sığar kategorisinde 6 kod yer almaktadır. Hayat eve sığar kategorisinin kodları; aile takibi, risk bölgeleri, uygulama (aplikasyon) içeriği, günlük tablo, test ve harita kodlarıdır. Hayat eve sığar kodlarının oluşturulmasında V17, V18, 
V19, V20, V21 ve V22 kodlu videolar kullanılmıştır. Videolarda dış ses yerine arka fonda müzik kullanılmış ve hayat eve sığar uygulaması ile ilgili yönergeler yazılı olarak verilmiştir. Videolardan elde edilen bulgulara göre, riski görün kategorisi 9 video ile hayat eve sığar kategorisi 6 video ile ve birlikte yeneceğiz kategorisi 5 video ile ifade edilmiştir.

\section{Sonuç ve Öneriler}

Çalışma, pandemi sürecinde Sağlık Bakanlığı tarafından hazırlanarak koruyucu sağlık hizmetleri kapsamında COVID-19 pandemi sürecinde yayınlanmış kamu spotlarının sosyal pazarlama açısından içerik analizleri yapılarak sonraki dönemlerde yapılacak çalışmalara genel çerçeve çizilmesi amaçlanmıştır. Bu kapsamda yayınlanmış olan 34 kamu spotunun içeriği analiz edilmiştir.

Çalışmanın birinci teması davranış kazandırmadır. Davranış kazandırma temasını oluşturan kodlar; hijyen kurallarına uyum ve evde bakımdır. Hijyen kurallarına uyum kodunun alt kodları; 14 kural, el yıkama kuralları ve diğer önlemler, maske kullanımı ve yapımıdır. Evde bakım alt kodları; ilaçların düzenli kullanımı, izolasyon, bağışıklı̆̆ güçlendirme, hasta takibine uyum, sağlık durumu takibi, gerekli durumlarda sağllk kuruluşlarına başvurmadır.

Çalışmanın ikinci teması farkındalıktır. Farkındalık temasını oluşturan kodlar; genel bilgilendirme ve sigara kullanımıdır. Genel bilgiler kodunun alt kodları; belirtiler, virüs hakkında genel bilgiler, bulaşım yolu, teşhis, belirtilerin olması durumu, filyasyon ve hastalığın sonuçlarıdır. Sigara kullanımı kodunun alt kodları; 14 kat daha savunmasız, sigara kullanımının tedaviyi zorlaştırması ve sigarayı bırakma zamanıdır.

Çalışmanın üçüncü teması ikna etmedir. İkna etme temasını oluşturan kodlar; riski görün, birlikte yeneceğiz ve hayat eve sığardır. Riski görün kodunun alt kodları; kuaför, AVM, sokak, asansör, berber, metro, pazaryeri, kafe ve restorandır. Birlikte yeneceğiz kodunun alt kodları; sosyal mesafe, maske, evde kal, izolasyon ve kronik hastalıklardır. Hayat eve sığar kodunun alt kodları; aile takibi, risk bölgeleri, uygulama (aplikasyon) içeriği, günlük tablo, test ve haritadır.

Kamu spotlarıyla insanlarda farkındalık oluşturulması, bu farkındalığın davranışa diğer bir ifadeyle yeni bir alışkanlığa dönüşmesi için insanların 
ikna edilmesini kapsayan bir süreç olarak değerlendirilmektedir. Sosyal pazarlamanın toplumsal etki düzeyi kamu spotlarıyla artırılmaya çalışılmaktadır. Pandemi sürecinde hasta sayılarının azaltılmasında sosyal pazarlama faaliyetlerinin büyük bir etkisinin olduğu düşünülmektedir.

Gelişmekte olan ülkelerde sosyal pazarlama ve kamu spotları yeterli düzeyde kullanılmamaktadır. Gelişmiş ülkelerde sosyal pazarlama felsefesi ve kamu spotları gelişmemiş ve gelişmekte olan ülkelere nispeten daha fazla anlaşıldığı, sosyal pazarlama ile ilgili kampanyaların sayısı ve çeşitliliği bağlamında ele alındığında kabul edilecek bir gerçektir. Sosyal pazarlama kampanyalarının sayısının ve çeşitliliğinin artırılması hem insanlığın hem de kamunun yararına olacaktır.

Sosyal pazarlama, davranışlarında mal ve hizmetler gibi pazarlamaya konu olabileceği fark edilmesinden bu yana pazarlama faaliyetlerine ayrı bir soluk getirmiştir. Özellikle sağlık alanında insanların bilinçlendirilmesi ülkeleri ilerleyen dönemlerde yapacağı sağlık harcamalarının miktarını da azaltma yönünde etkisi bulunmaktadır. Kamu spotlarında özellikle korku unsurunun kullanılarak insanların etkilenmesi sağlanmakta, dolayısıyla da insanların istenilen davranışa yönlendirilmesi yapılmaktadır. Sağlık alanında koruyucu sağlık hizmetleri kapsamında kullanılan sosyal pazarlama kampanyaları ile ilgili obezite ile mücadele edilmesi, sigara kullanımı ile mücadele edilmesi, bulaşıcı hastalıklarla mücadele edilmesi gibi konularda insanların istenilen davranışlara yönlendirilmesi konusunda bilinç oluşturmaya çalışmaktadır. COVID-19 ile mücadele edildiği günümüzde, Sağlık Bakanlığ insanları salgın konusunda bilgilendirmek için kamu spotları ve alanın da uzman kişilere röportaj yapma imkanı vermektedir. Kamu spotlarıly pandemi sürecinde seyahat yapan kişilerin nelere dikkat etmesi gerektiği, sigara kullanımının virüsün bulaşmasını kolaylaştırdığı, hayat eve sığar uygulamasıyla insanların hareketliliğini azaltması gerektiği, virüsle mücadelede alınması gereken önlemler, maske, mesafe ve temizlik konularında insanlara bilgilendirme yapılmaktadır.

Sağlık Bakanlığı tarafından oluşturulmuş kamu spotlarının sosyal pazarlamada kullanılan eğitim, farkındalık oluşturma, ikna etme, toplumu etkileme gibi yaklaşımlara ve kullanım amaçlarına uygun olduğu ortaya çıkmıştır. Çalışma sonucunda ortaya çıkan davranış kazandırma, farkındalık ve 
ikna etme temaları sonraki dönemde yapılacak çalışmaların bu temalar ekseninde şekillendirilmesi konusunda literatüre katkı yapacağı düşünülmektedir.

Sadece Sağlık bakanlığının pandemi sürecinde yayınlamış olduğu kamu spotlarının kullanılması ve bu kamu spotlarından da bilim kurulu üyelerinin yer aldığı ropörtaj kamu spotlarının eklenmemiş olması araştırmanın kısıtları arasında yer almaktadır. Bu sinırlılılar gözönünde bulundurulduğunda daha kapsamlı sayıca fazla kamu spotu kullanılarak yeni çalışmalar yapılabilir. Ayrıca diğer bakanlıkların sosyal pazarlama bağlamında insanları bilinçlendirmek ve toplumsal faydayı ön planda tutmak için yapmış oldukları kamu spotları da bu çalıma göz önünde bulundurularak yapılabilecektir. Bunlara ek olarak temalaştırılan içerikler göz önünde bulundurularak odak grup görüşme yöntemiyle kamu spotlarının toplumsal etki düzeyi (diğer bir ifadeyle kişileri nasıl etkilediği) araştırılacak konular arasında yer almaktadır. Ayrıca insanlarda farkındalık oluşturup davranış değiştirmeleri konusunda ikna olup olmadıklarını ve verilmek istenen mesajları doğru algılayıp algılamadıklarını ortaya çıkarılması konusunda yeni çalışmalara bu çalışmanın zemin hazırlayacağı düşünülmektedir. 


\section{EXTENDED ABSTRACT}

\section{Use of Public Service Announcements as A Social Marketing Tool in Managing the COVID-19 Pandemia Process: A Content Analysis \\ Özgür Yeşilyurt \\ Muş Alparslan University}

Social marketing is used as a marketing activity that creates awareness with regards to solving social problems, features social benefit, and aims at attitude and behavioral change related to the social problems. Social marketing is utilized within the framework of education, persuasion, behavioral change and social impact paradigms.

Elements of marketing mix in social marketing activities during the pandemic process are given below.

- Product: It refers to testing in case of symptoms related to the outbreak, generalizing the use of protective equipment such as masks and gloves, complying with all social distancing environments and paying attention to hygiene conditions in daily life. (Generally used as Mask-DistanceCleaning in public service announcements (PSAs).)

- Price: It refers to the equipment fees used for protection against virus, the care fees of the people infected with virus, the test fees used to detect the presence of the virus, and the protective equipment fees.

- Place: This refers to public and private hospitals, institutions and organizations that support the place and sale of protective equipment.

- Promotion: Interviews given by healthcare professionals who are specialists in their field, public service announcements created with the support of the Ministry of Health and broadcast in several media, and distribution of free masks by state in order to attract the attention of people at the beginning of the pandemic and to gain sensitivity to reduce the spread of the virus are among the examples that can be given.

- Public opinion: It refers to everyone who causes the spread of the virus and struggle with the virus.

- Partnership: It refers to national and international healthcare organizations which attempt to prevent the spread of the virus, and national and 
international organizations which ensure the production and distribution of protective equipment and vaccines.

- Politics: It refers to taking measures that will reduce the spread of the virus by allocating budgets to struggle with the virus, to develop policies to be used in struggling with the virus by state institutions and organizations, and to develop policies to be used by private organizations in struggling with the virus.

- Funders: It refers to the subsidy to be given to the people, institutions and organizations doing research in order to stop the spread of virus. It includes state subsidies and government grants. (Vaccination studies are supported by the government and private organizations with funds and grants.)

In our country, institutions and organizations, Ministries (such as the Ministry of Health, the Ministry of Environment and Urbanization, the Ministry of Interior), and non-governmental organizations that make public service announcements generally use them as a social marketing tool. It is generally used in health related fields. Social marketing activities that explain the harms of smoking for smoking cessation, raise awareness of the public for donation of organs and raise awareness about some types of cancer are used extensively. Today, when the corona virus is fought, social marketing activities are used to raise the awareness of the public in order to reduce and to stop the spread of the outbreak. In order to raise the awareness of the public, it is tried to bring up the issues that people should pay attention to by shooting public spots and explaining the measures people should take against the virus. Promotion campaigns and public service announcements are used extensively to raise awareness of people in preventive healthcare services and to eliminate situations that may cause social problems in the field of health. This study has been performed in order to raise the awareness of people in the management of the pandemic process through public service announcements prepared with the support of the Ministry of Health, and to ensure that the public service announcements in various channels are themed in the context of social marketing by reducing the spread of the outbreak. It is considered that this study will form a basis for new studies to see whether or not people perceive the messages intended to be given in public service announcements correctly and to see its level of social impact. 
This is to theme 34 public service announcements created with the support of the Ministry of Health during the COVID-19 pandemic process in the context of social marketing.

The method of the study is to theme 34 public service announcements broadcast by the Ministry of Health in the context of social marketing during the COVID-19 pandemic process by using content analysis. Videos related to public service announcements were coded and themes created by the means of the program used in qualitative data analysis

The first theme of the study is to gain behavior. The codes that constitute the theme of gaining behavior are the compliance with hygiene rules and home care. The second theme of the study is awareness. The codes that constitute the awareness theme are general information and smoking. The third theme of the study is persuasion. The codes that constitute the theme of persuasion are "see the risk, we will beat together, and life fits into home".

Social marketing and public service announcements are not used adequately in developing countries. Greater understanding of social marketing philosophy and public service announcements in developed countries compared to underdeveloped and developing countries is an acceptable fact when considered in the context of the number and diversity of campaigns related to social marketing. Increasing the number and diversity of social marketing campaigns will be for the benefit of both humanity and the public.

Social marketing has given a different new pulse to marketing activities since it was realized that it could be subject to marketing like goods and services in their behaviors. Especially raising awareness of people in the field of health has an effect on reducing the amount of health expenditures that countries will spend in the future. Especially, by using the fear element in public service announcements, it is ensured to influence people, and therefore, people are directed to the desired behavior.

With the social marketing campaigns used within the scope of preventive health services in the field of health, it tries to raise awareness about directing people to desired behaviors in issues such as struggling with obesity, struggling with smoking, struggling with infectious diseases etc. Today, in struggling with COVID-19, the Ministry of Health provides public service announcements and the opportunity to interview with those specialists in their field in order to inform people about the outbreak. With public service announcements, people are informed about what traveller people should pay 
attention to during the pandemic process, smoking that facilitates the transmission of the virus, the necessity of reducing people's mobility with the practice "life fits into home" and measures to be taken in struggling with the virus such as masks, distance and cleaning.

Among the limitations of the study is the use of only the public service announcements broadcast by the Ministry of Health during the pandemic process and the absence of interviews with the members of the scientific committee. Considering these limitations, new studies can be performed by using more comprehensive public service announcements. Also, public service announcements by other ministries in order to raise awareness of people in the context of social marketing and to prioritize social benefit can be made by considering this study. In addition to these, considering the themed contents, the social impact level of public service announcements (in other words, how they affect people) with focus group interview method is among the topics to be studied. In addition, it is thought that this study will form a basis for new studies to reveal whether or not people are convinced about creating awareness and changing behaviors and whether or not they perceive the messages given correctly.

\section{Kaynakça / References}

Andreasen, A. R. (1994). Social marketing: Its definition and domain. Journal of Public Policy \& Marketing, 13(1), 108-114. doi:10.1177/074391569401300109.

Andreasen, A. R. (1995), Marketing social change. San Fransisco: Jossey Bass.'den Akt Dinan, C. ve Sargeant, A. (2000). Social marketing and sustainable tourism: Is there a match?, Journal of Tourism Research, 2(1), 1-14.

Bayın, G. ve Akbulut, Y. (2012). Sağlık sektöründe sosyal pazarlamanin kullanimi. Ankara Sağllk Bilimleri Dergisi, 53-72.

Bilgiç, B. (2016). Türkiye'de kamu spotu oluşum süreci ve yayın politikaları. İletişim Çalışmaları Dergisi. 1, 25-61.

Boone, L. E. ve Kurtz, D. L. (2012). Contemporary marketing. (15th Edition). USA: South-Western Cengage Learning.

Can, P. (2017). Sosyal pazarlama kurumsal sosyal sorumluluk ekseninde. (1. Baskı). İstanbul: Kriter Yayıncllı. 
Dinan, C. ve Sargeant, A. (2000). Social marketing and sustainable tourism: Is there a match?. Journal of Tourism Research, 2(1), 1-14.

Eser, Z. ve Özdoğan, B. (2006). Sosyal pazarlama toplumun refahi ve kaliteli yaşami İçin. Ankara : Siyasal Kitabevi.

Gençoğlu, P., Bağlitaş, H. H. ve Kuşkaya, S. (2017). Sosyal pazarlama araci olarak kamu spotlarinin birey davranişlari üzerindeki etkileri: Parametrik olmayan istatistiksel bir analiz. Ululsarası Sosyal Çalışmalar Dergisi, 10(48), 622-629.

Gümüs, S. ve Toy, D. (2013). Sağglk hizmetlerinin pazarlamasi ve reklamin etkileri. (1. Baskı). İstanbul: Hidperlink Yayıncllık.

Kotler, P. ve Lee, N. R. (2010). Yoksulluğa Karşı Sosyal Pazarlama. (Çev. Z. Kökkaya Chalar). Up and Out of Poverty: The Social Marketing Solution. İstanbul: Kapital Medya Hizmetleri.

Kurt, A., ve Yılmaz Alarçi, E. (2019). Sağlık alanındaki kamu spotlarına ilişkin tutum ve beklentilerin değerlendirilmesi. Süleyman Demirel Üniversitesi Vizyoner Dergisi, 10(24). 364-378.

Lee, N. R. ve Kotler, P. (2020). Sosyal pazarlama sosyal fayda için davraniş değiş̧imi. (6. Baskı). (Haz. G. Özer). İstanbul: Cinius Yayıncilık.

Marangoz, M. ve Aydın, A.E. (2019). Sosyal pazarlama: Ilkeler ve uygulamalar. İstanbul: Beta Basım Yayın.

Nurtanış Velioğlu, M., ve Çoknaz, D. (2010). Sosyal pazarlama. İ. Varinli \& K. Çatı (Der.) Güncel Pazarlama Yaklaşımlarından Seçmeler içinde (455-478). (2. Bask1). Ankara: Detay Yayınclık.

Özer, G. C. (2020). Sosyal pazarlama kavraminin analizi ve geleceği. (1. Baskı). İstanbul :Cinius Yayınları.

Ruiter, R. A. C., Abraham, C. ve Kok, G. (2001). Scary warnings and rational precautions: A review of the psychology of fear appeals. Psychology $\mathcal{E}$ Health, 16(6), 613-630. doi:10.1080/08870440108405863.

Weinreich, N. K. (2006). Weinreich communications. 02.01.2021 tarihinde http://www.social-marketing.com/whatis.html adresinden erişilmiştir.

Yıldırım Becerikli, S. (2012). Sağlık iletişimi çalışmalarında alımlama analizinin kullanımı: Odak grup çalışması yoluyla kamu kampanyaları ve reklam metinlerine ilişkin çapraz bir okuma pratiği. İstanbul Üniversitesi İletişim Fakültesi Dergisi, 2(43), 163-177.

Zalluhoğlu, A. E., Karslı, C., Candemir, A. ve Günay, G. N. (2015). Sosyal pazarlama çerçevesinde kamu spotlarinin incelenmesi: Keşifsel bir analiz. 20. Ulusal Pazarlama Kongresi, 467-478. 


\section{Kaynakça Bilgisi / Citation Information}

Yeşilyurt, Ö. (2021). COVID-19 pandemi sürecinin yönetilmesinde sosyal pazarlama aracı olarak kamu spot-ların incelenmesi: İçerik analizi. OPUS-Uluslararası Toplum Araştırmaları Dergisi, 17(Pandemi Özel sayıs1), 3470-3500. DOI: 10.26466/opus.855071 